\title{
Covid-19, Conflict, and Governance Evidence Summary No.30
}

\author{
Siân Herbert \\ GSDRC \& K4D, University of Birmingham \\ 26 February 2021
}

This fortnightly Covid-19 (C19), Conflict, and Governance Evidence Summary aims to signpost the UK Foreign, Commonwealth and Development Office (FCDO) and other UK government departments to the latest evidence and opinions on C19, to inform and support their responses. Based on feedback given in a recent survey, and analysis by the Xcept project, this summary is now focussing more on $\mathrm{C} 19$ policy responses.

This summary features resources on: how youth empowerment programmes have reduced violence against girls during C19 (in Bolivia); why we need to embrace incertitude in disease preparedness responses; and how Latin American countries have been addressing widening gender inequality during $\mathrm{C} 19$.

It also includes papers on other important themes: the role of female leadership during C19; and understanding policy responses in Africa to $\mathrm{C} 19$

The summary uses two main sections - (1) literature: - this includes policy papers, academic articles, and long-form articles that go deeper than the typical blog; and (2) blogs \& news articles. See the end of this report for details on the method taken for this rapid summary. It is the result of one day of work, and is thus indicative but not comprehensive of all issues or publications. 


\section{LITERATURE}

\section{GOVERNANCE}

\begin{tabular}{|c|c|c|}
\hline Title/URL & $\begin{array}{l}\text { Name of } \\
\text { author; } \\
\text { publisher; } \\
\text { publication } \\
\text { type }\end{array}$ & Summary \\
\hline $\begin{array}{l}\text { Rethinking disease } \\
\text { preparedness: incertitude and } \\
\text { the politics of knowledge }\end{array}$ & $\begin{array}{l}\text { Melissa } \\
\text { Leach, Hayley } \\
\text { MacGregor, } \\
\text { Santiago } \\
\text { Ripoll, Ian } \\
\text { Scoones \& } \\
\text { Annie } \\
\text { Wilkinson; } \\
\text { Critical Public } \\
\text { Health; } \\
\text { Journal article }\end{array}$ & $\begin{array}{l}\text { How should C19 shape approaches to } \\
\text { disease preparedness? This journal article } \\
\text { argues for a rethinking of disease } \\
\text { preparedness that puts incertitude and the } \\
\text { politics of knowledge at the centre. } \\
\text { Through examining the experiences of } \\
\text { Ebola, Nipah, cholera and C19 across } \\
\text { multiple settings, the limitations of current } \\
\text { approaches are highlighted. Conventional } \\
\text { approaches assume a controllable, } \\
\text { predictable future, which is responded to by } \\
\text { a range of standard interventions. Such } \\
\text { emergency preparedness planning } \\
\text { approaches assume risk - where future } \\
\text { outcomes can be predicted - and fail to } \\
\text { address uncertainty, ambiguity and } \\
\text { ignorance - where outcomes or their } \\
\text { probabilities are unknown. Through } \\
\text { examining the experiences of outbreak } \\
\text { planning and response across the four } \\
\text { cases, the paper argues for an approach } \\
\text { that highlights the politics of knowledge, the } \\
\text { constructions of time and space, the } \\
\text { requirements for institutions and } \\
\text { administrations and the challenges of } \\
\text { ethics and justice. Embracing incertitude in } \\
\text { disease preparedness responses therefore } \\
\text { means making contextual social, political } \\
\text { and cultural dimensions central. }\end{array}$ \\
\hline $\begin{array}{l}\text { Santiago Commitment: A } \\
\text { regional instrument to respond } \\
\text { to the COVID-19 crisis with } \\
\text { gender equality }\end{array}$ & $\begin{array}{l}\text { Economic } \\
\text { Commission } \\
\text { for Latin } \\
\text { America and } \\
\text { the Caribbean }\end{array}$ & $\begin{array}{l}\text { How can the Santiago Commitment be } \\
\text { used to address gender inequality during } \\
\text { C19? This paper explains how in the } \\
\text { Santiago Commitment, Latin American } \\
\text { governments agreed to implement gender- } \\
\text { sensitive countercyclical policies to mitigate } \\
\text { the impacts of economic crises and }\end{array}$ \\
\hline
\end{tabular}




\begin{tabular}{|c|c|c|}
\hline & $\begin{array}{l}\text { (ECLAC); } \\
\text { Policy paper }\end{array}$ & $\begin{array}{l}\text { recessions on women's lives, among other } \\
\text { commitments. It provides examples of } \\
\text { regional government responses during C19 } \\
\text { related to: } \\
\text { - Gender-based violence - including: } \\
\text { strengthening of services and expansion } \\
\text { of the channels of assistance for women } \\
\text { in situations of violence; and access to } \\
\text { justice, with the extension of } \\
\text { precautionary measures, mobility permits } \\
\text { and use of media. } \\
\text { - The care economy - including: care } \\
\text { services, travel permits, leave for } \\
\text { caregivers, campaigns about co- } \\
\text { responsibility for care, and the rights of } \\
\text { domestic workers } \\
\text { - Social protection - including: cash } \\
\text { transfers; and in-kind transfers } \\
\text { - Employment and income generation - } \\
\text { employment protection and access to } \\
\text { credit; and support for women in micro, } \\
\text { small and medium-sized enterprises } \\
\text { It recommends: } \\
\text { - Reverse the trend of deepening poverty } \\
\text { and precarious living conditions of women } \\
\text { in the region as a result of the C19 crisis } \\
\text { - Strengthen prevention and care for } \\
\text { women in situations of gender-based } \\
\text { violence in the context of the pandemic } \\
\text { - Promote fiscal stimulus packages } \\
\text { - Promote women's participation in } \\
\text { - Transform the sexual division of labour }\end{array}$ \\
\hline $\begin{array}{l}\text { The power that comes from } \\
\text { within: female leaders of Rio de } \\
\text { Janeiro's favelas in times of } \\
\text { pandemic }\end{array}$ & $\begin{array}{l}\text { Nilza Rogeria } \\
\text { De Andrade } \\
\text { Nunes; Global } \\
\text { Health } \\
\text { Promotion; } \\
\text { Journal article }\end{array}$ & $\begin{array}{l}\text { What roles are female leaders in Rio's } \\
\text { favelas playing in the C } 19 \text { response? } \\
\text { Drawing on interviews with } 111 \text { women } \\
\text { living in favelas, this journal article finds } \\
\text { that } 97 \% \text { say they support health promotion } \\
\text { through the strengthening of popular } \\
\text { participation towards community } \\
\text { development and defence of rights, and } \\
\text { mobilisation of health services to meet } \\
\text { needs. With the presence of public agents }\end{array}$ \\
\hline
\end{tabular}




\begin{tabular}{|l|l|l|} 
& & $\begin{array}{l}\text { restricted during C19, these women often } \\
\text { take up the duties of the local authorities to } \\
\text { ensure food security, good communication } \\
\text { among local residents on health standards, } \\
\text { hygiene measures, assistance to the most } \\
\text { vulnerable, etc. }\end{array}$ \\
\hline 19: The Reckoning of Agency? & $\begin{array}{l}\text { Amy S. } \\
\text { Patterson \& } \\
\text { Emmanuel } \\
\text { Balogun; } \\
\text { African } \\
\text { Studies } \\
\text { Review; } \\
\text { Journal Article }\end{array}$ & $\begin{array}{l}\text { What explains African countries' responses } \\
\text { to C19? Drawing on analysis of the Africa } \\
\text { Centres for Disease Control and } \\
\text { Prevention and various states collaborating } \\
\text { with civil society, this article argues that } \\
\text { responses display forms of agency rooted } \\
\text { in contextually relevant expertise, pan- } \\
\text { African solidarity, and lessons learned } \\
\text { about health messaging and community } \\
\text { mobilisation from previous health crises. } \\
\text { Yet collaboration has not always been } \\
\text { harmonious, as actors have adopted } \\
\text { various approaches in their interactions } \\
\text { with global health institutions and civil } \\
\text { society partnerships, and they have } \\
\text { actively debated the use of traditional } \\
\text { medicine as a C19 treatment. }\end{array}$ \\
\hline
\end{tabular}

Extra papers - without summary

\begin{tabular}{|l|l|}
\hline Title/URL & $\begin{array}{l}\text { Name of author; publisher; } \\
\text { publication type }\end{array}$ \\
\hline $\begin{array}{l}\text { Post-Covid-19 Recovery and Resilience: Leveraging } \\
\text { Reformsfor Growth and Inclusionin Sub-Saharan } \\
\text { Africa }\end{array}$ & $\begin{array}{l}\text { Paola Ganumand \& Vimal Thakoor; } \\
\text { Working paper; IMF }\end{array}$ \\
\hline $\begin{array}{l}\text { Withstanding the plague: Institutional resilience of the } \\
\text { East Asian welfare state }\end{array}$ & $\begin{array}{l}\text { Suetgiin Soon, Chelsea C. Chou \& } \\
\text { Shih-Jiunn Shi; Social Policy \& } \\
\text { Administration; Journal article }\end{array}$ \\
\hline The Global Impact of COVID-19 & $\begin{array}{l}\text { Various; Southasiadisasters.net; } \\
\text { Journal }\end{array}$ \\
\hline
\end{tabular}




\section{CONFLICT}

\begin{tabular}{|c|c|c|}
\hline Title/URL & $\begin{array}{l}\text { Name of } \\
\text { author; } \\
\text { publisher; } \\
\text { publication } \\
\text { type }\end{array}$ & Summary \\
\hline $\begin{array}{l}\text { Can Youth Empowerment } \\
\text { Programs Reduce Violence } \\
\text { against Girls during the } \\
\text { COVID-19 Pandemic? }\end{array}$ & $\begin{array}{l}\text { Selim } \\
\text { Gulesci, } \\
\text { Manuela } \\
\text { Puente } \\
\text { Beccar \& } \\
\text { Diego Ubfal, } \\
\text { Working } \\
\text { Paper; World } \\
\text { Bank }\end{array}$ & $\begin{array}{l}\text { Can youth empowerment programmes } \\
\text { reduce violence against girls during C19? } \\
\text { Drawing on a randomised control trial with } \\
600 \text { vulnerable adolescents, this paper finds } \\
\text { that a youth empowerment program in } \\
\text { Bolivia reduces the prevalence of violence } \\
\text { against girls during the C19 lockdown } \\
\text { through offering training in soft skills and } \\
\text { technical skills, sex education, mentoring, } \\
\text { and job-finding assistance. The results } \\
\text { indicate that seven months after its } \\
\text { completion, the programme increased girls' } \\
\text { earnings and decreased violence targeting } \\
\text { females. Violence is measured with both } \\
\text { direct self-report questions and list } \\
\text { experiments. These findings suggest that } \\
\text { empowerment programs can reduce the } \\
\text { level of violence experienced by young } \\
\text { females during high-risk periods. }\end{array}$ \\
\hline
\end{tabular}

\section{BLOGS \& NEWS ARTICLES}

\section{GOVERNANCE}

Blogs \& news articles - without summary

\begin{tabular}{|l|l|}
\hline Title/URL & $\begin{array}{l}\text { Name of author; publisher; } \\
\text { publication type }\end{array}$ \\
\hline $\begin{array}{l}\text { Failures with COVID-19 at the international level must } \\
\text { not be repeated in an era facing global catastrophic } \\
\text { biological risks }\end{array}$ & $\begin{array}{l}\text { Matt Boyd \& Nick Wilson; Australian } \\
\text { and New Zealand Journal of Public } \\
\text { Health; Letter }\end{array}$ \\
\hline $\begin{array}{l}\text { From National Interest to Global Responsibility: } \\
\text { Vaccine Nationalism and the World Trade } \\
\text { Organisation (WTO) }\end{array}$ & Vasu Gounden; ACCORD; blog \\
\hline
\end{tabular}


How President Bolsonaro used COVID-19 to erode Brazil's democracy

'Politics was always in the room.' WHO mission chief reflects on China trip seeking COVID-19's origin
Flavia Bellieni Zimmermann; Open Democracy; blog

Kai Kupferschmidt; Science; Feature

\section{CONFLICT}

\begin{tabular}{|l|l|l|}
\hline Title/URL & $\begin{array}{l}\text { Name of } \\
\text { author; } \\
\text { publisher; } \\
\text { publication } \\
\text { type }\end{array}$ & Summary \\
\hline $\begin{array}{l}\text { Visualising the world's } \\
\text { response to Covid-19 through } \\
\text { online trackers }\end{array}$ & $\begin{array}{l}\text { Devanjan } \\
\text { Bhattachary } \\
\text { \& Anne } \\
\text { Funnemark; } \\
\text { IDS; Blog }\end{array}$ & $\begin{array}{l}\text { To help inform research on the nexus } \\
\text { between peace, conflict, and C19, the } \\
\text { Political Settlements Research Programme } \\
\text { (PSRP) at the University of Edinburgh has } \\
\text { created a Library of Trackers, a curated } \\
\text { collection of online trackers that monitor and } \\
\text { visualise social, political and economic } \\
\text { developments during C19. }\end{array}$ \\
\hline
\end{tabular}

\section{Blogs \& news articles - without summary}

\begin{tabular}{|l|l|}
\hline Title/URL & $\begin{array}{l}\text { Name of author; publisher; } \\
\text { publication type }\end{array}$ \\
\hline $\begin{array}{l}\text { UK foreign secretary calls for coronavirus 'vaccine } \\
\text { ceasefires' in conflict zones }\end{array}$ & Politico; News \\
\hline
\end{tabular}




\section{VIDEOS \& PODCASTS}

\begin{tabular}{|l|l|l|}
\hline Title/URL & $\begin{array}{l}\text { Name of } \\
\text { author; } \\
\text { publisher; } \\
\text { publication } \\
\text { type }\end{array}$ & Summary \\
\hline Resilience & $\begin{array}{l}\text { LSE; Event } \\
\text { audio }\end{array}$ & $\begin{array}{l}\text { This event audio explores the meaning of the term } \\
\text { 'resilience', tracing the philosophical traditions of } \\
\text { resilience and exploring critical perspectives on its } \\
\text { modern forms. }\end{array}$ \\
\hline
\end{tabular}

\section{EVENTS}

2 March - 12:00-13:30 - The politics of evidence in global emergencies - Lessons from Covid19, IDS. This event explores the role of experts and the politics of C19 knowledge in different global contexts. It asks how researchers, public health officials and policy actors can work better together during periods of acute uncertainty.

11 March - 15:00-16:30 - Horizon 2025-End of the beginning: Development cooperation in the pandemic age, IDS. This event explores how C19 may be amplifying and changing the nature of development challenges and how global development cooperation should adapt, focussing on changes to global growth, debt, budget deficits and taxes, aid, capital markets, along with poverty and vulnerability. The event speakers will propose that aid is moving further beyond altruism to become more of an instrument of national self-interest and of better planetary management of the global commons. Metrics of environmental sustainability and social inclusion performance, as well as governance, will become more important determinants of aid's effectiveness. Prominent among these is far more ambitious use of multilateral and national development banks, and global policies to reduce capital outflows from developing countries.

11 March 2021 - 17:00-18:00 - Covid-19 and development: debt dynamics and sustainability, IDS. 


\section{DASHBOARDS, TRACKERS \& RESOURCE HUBS}

K4D - Covid-19 Resource Hub

ACAPS - Covid-19 ACAPS Resources

ACAPS - Secondary impacts of C19

ACLED - Covid-19 disorder tracker

African Arguments - Coronavirus in Africa Tracker

CGD - Coronavirus preparedness \& response

ConnexUs - Resource library on COVID-19 responses, social cohesion, conflict dynamics, behaviour-change communications, and health, aid, and peacebuilding collaboration

Council on Foreign Relations - Peace, Conflict, and Covid-19

COVID-19 Humanitarian - COVID-19 and Humanitarian Crises

COVID-DEM - COVID-19 and democratic governance

Dalia research - Democracy Perception Index 2020

ECPR Standing Group on Organised Crime - Controcorrente (dedicated Covid-19 blog series)

European Council on Foreign Relations - European solidarity tracker

Gender and Covid-19 - Gender and Covid-19

GI-TOC - Covid Crime Watch

Global Voices - Covid-19: Global voices for a pandemic

ICNL - COVID-19 Civic Freedom Tracker

IDS - Covid-19: the social science response to the pandemic

Insecurity insight - Covid-19 and security monitoring

International IDEA - Global Monitor of COVID-19's impact on Democracy and Human Rights

International IDEA - Global overview of COVID-19: Impact on elections

International Social Security Association (ISSA) - Coronavirus country measures

IPA - RECOVR Research Hub

K4D - COVID-19 Evidence Search

KPMG - Covid-19 tax developments

ODI - Reforms, initiatives and campaigns on migrants' contributions to the Covid-19 response

OECD - Tackling coronavirus (COVID-19) Contributing to a global effort resource hub 
OECD States of Fragility - Covid-19, Crises, and Fragility

Political Settlements Research Programme - Conflict, development and Covid-19 resources

Political Settlements Research Programme - COVID-19 Trackers Library

ReliefWeb - Covid-19 Global Hub

The Economist - Covid-19 news

The New Humanitarian - Coronavirus news, data, and policy response tracker

The Syllabus - The politics of Covid-19 readings

UNDP - COVID-19 Global Gender Response Tracker

University of Oxford - Coronavirus Government Response Tracker

University of Oxford - Oxford Supertracker

Various - Crowd-sourced cross-disciplinary coronavirus syllabus

V-Dem Institute - Pandemic Democratic Violations Index

Westminster Foundation for Democracy - Pandemic Democracy Tracker

World Bank - COVID-19 High-Frequency Monitoring Dashboard

\section{Suggested citation}

Herbert, S. (2021). COVID-19 Conflict and Governance Evidence Summary No.30. K4D

Evidence Summary. Brighton, UK: Institute of Development Studies. DOI:

10.19088/K4D.2021.028

\section{Methodology}

Due to the emerging nature of the Covid-19 crisis, this rapid weekly summary includes blogs, and news articles, in addition to policy and academic literature. The sources included are found through searches of Google and ReliefWeb with the keywords:

(“COVID-19" OR "coronavirus") AND ("developing countries" OR "Africa" OR "Asia" OR "Middle East" OR "Latin America" OR "Pacific") AND ("conflict" OR "peace" OR "violence" OR "resilience" OR "fragility")

("COVID-19" OR "coronavirus") AND ("authoritarian*" OR "democracy" OR "corrupt" OR "transparency" OR "state legitimacy" OR "non-state actors" OR "state capacity" OR "state authority" OR "politic" OR "state institutions")

Plus searches of Google Scholar with the keywords:

(“COVID-19" OR "coronavirus") AND ("developing countries" OR "Africa" OR "Asia" OR "Middle East" OR "Latin America" OR "Pacific") 
("COVID-19" OR "coronavirus") AND ("developing countries" OR "Africa" OR "Asia" OR "Middle East" OR "Latin America" OR "Pacific") AND ("conflict" OR "peace" OR "violence" OR "resilience" OR "fragility")

("COVID-19" OR "coronavirus") AND ("authoritarian*” OR "democracy" OR "corruption" OR "transparency" OR "state legitimacy" OR "non-state actors" OR "state capacity" OR "state authority" OR "politic*" OR "state institutions")

The searches are restricted to articles published in the previous seven days, in English. This is complemented by: a focussed Twitter search (using just the pages of a small selection of research organisations, and key scholars/thinkers, including those funded by the UK government's FCDO; and through email recommendations from FCDO advisors and leading experts. This is trial and error approach, which will be refined and changed over the coming weeks. If you have literature to include in the weekly summary, please email - s.herbert@bham.ac.uk

Thanks to Professor Heather Marquette for expert advice.

\section{About this report}

This two-weekly COVID-19 conflict and governance evidence summary is based on 1 day of desk-based research. K4D services are provided by a consortium of leading organisations working in international development, led by the Institute of Development Studies (IDS), with Education Development Trust, Itad, University of Leeds Nuffield Centre for International Health and Development, Liverpool School of Tropical Medicine (LSTM), University of Birmingham International Development Department (IDD) and the University of Manchester Humanitarian and Conflict Response Institute (HCRI).

This evidence summary was prepared for the UK Government's Foreign, Commonwealth and Development Office (FCDO) and its partners in support of pro-poor programmes. Except where otherwise stated, it is licensed for non-commercial purposes under the terms of the Open Government Licence v3.0. K4D cannot be held responsible for errors, omissions or any consequences arising from the use of information contained in this conflict and governance evidence summary. Any views and opinions expressed do not necessarily reflect those of FCDO, K4D or any other contributing organisation.

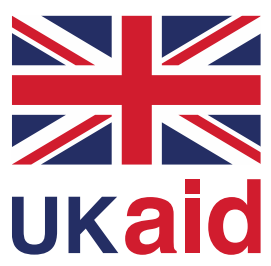

(C) Crown copyright 2021. 